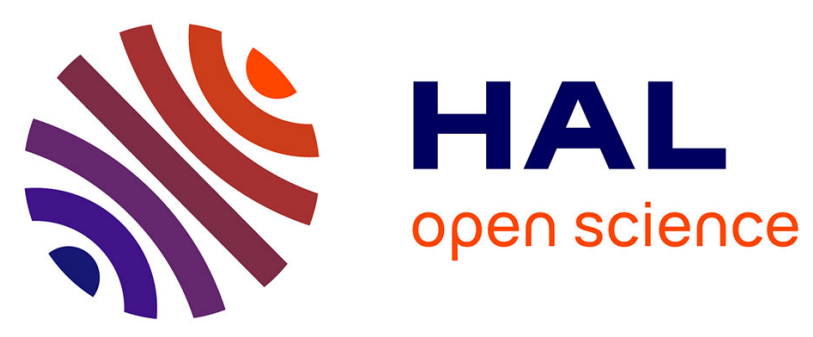

\title{
Development of Enzymatic Biosensors to Detect Biocide Disinfectants to Strengthen Self-Monitoring in Industry
}

Valerie Gaudin, Christophe Soumet

\section{To cite this version:}

Valerie Gaudin, Christophe Soumet. Development of Enzymatic Biosensors to Detect Biocide Disinfectants to Strengthen Self-Monitoring in Industry. Engineering Proceedings, 2021, 6 (1), pp.36. 10.3390/I3S2021Dresden-10077 . anses-03378770

\section{HAL Id: anses-03378770}

https://hal-anses.archives-ouvertes.fr/anses-03378770

Submitted on 14 Oct 2021

HAL is a multi-disciplinary open access archive for the deposit and dissemination of scientific research documents, whether they are published or not. The documents may come from teaching and research institutions in France or abroad, or from public or private research centers.
L'archive ouverte pluridisciplinaire HAL, est destinée au dépôt et à la diffusion de documents scientifiques de niveau recherche, publiés ou non, émanant des établissements d'enseignement et de recherche français ou étrangers, des laboratoires publics ou privés.

\section{(c)(1)}

Distributed under a Creative Commons Attribution/ 4.0 International License 


\title{
Development of Enzymatic Biosensors to Detect Biocide Disinfectants to Strengthen Self-Monitoring in Industry ${ }^{+}$
}

\author{
Valérie Gaudin * and Christophe Soumet (D)
}

\author{
Laboratory of Fougeres, European Union Reference Laboratory (EU-RL) for Antimicrobial and Dye Residue \\ Control in Food-Producing Animals, Bâtiment Bioagropolis-La Haute Marche-Javené, 35302 Fougères, France; \\ christophe.soumet@anses.fr \\ * Correspondence: valerie.gaudin@anses.fr \\ + Presented at the 8th International Symposium on Sensor Science, 17-28 May 2021; Available online: \\ https://i3s2021dresden.sciforum.net/.
}

Citation: Gaudin, V.; Soumet, C. Development of Enzymatic Biosensors to Detect Biocide Disinfectants to Strengthen Self-Monitoring in Industry. Eng. Proc. 2021, 6, 36. https://doi.org/ 10.3390/I3S2021Dresden-10077

Academic Editors: Gianaurelio Cuniberti and Larysa Baraban

Published: 17 May 2021

Publisher's Note: MDPI stays neutral with regard to jurisdictional claims in published maps and institutional affiliations.

Copyright: (c) 2021 by the authors. Licensee MDPI, Basel, Switzerland. This article is an open access article distributed under the terms and conditions of the Creative Commons Attribution (CC BY) license (https:/ / creativecommons.org/licenses/by/ $4.0 /)$.

\begin{abstract}
Biocide disinfectants are used in agro-food industries in order to limit the development of pathogens present in environment or on surfaces in contact with food for human or animal consumption. Biocide residues remaining on food surfaces may constitute a toxicological risk for the consumer. Very little feedback from the field on the rates of biocide residues in the industry exist due to a lack of simple, fast and responsive self-checking methods. The development of biosensors for the detection of biocide disinfectants represents a promising way to explore this, but most of this research remains limited.
\end{abstract}

Keywords: biocides disinfectants; enzymatic biosensors; optical; electrochemical; food products

\section{Introduction}

The implementation of cleaning and disinfection plans, essential elements in the control of hygiene and food safety for consumers, is a requirement of the "Food Law" (Regulation EC 852/2004) [1]. A wide variety of these products are used on a daily basis throughout the food chain to limit the development of undesirable microorganisms present in the environment or on surfaces in contact with food intended for human or animal consumption. Following these treatments, biocidal product residues may persist on the surfaces, in particular if these residues are not completely removed during rinsing operations. It has also been proven that their transfer to food is possible. In 2012, a European Food Safety Agency (EFSA) investigation found excessive amounts of two quaternary ammonium compounds (QACs) [2]. The greatest number of positive results $(12 \%)$ was found in milk and dairy products, with contamination levels ranging from a few tens to a few thousand $\mu \mathrm{g} / \mathrm{kg}$. The presence of residues may be associated with (i) toxicological risks and (ii) emergence of resistance to biocides and cross-resistance with antibiotics. Therefore, cleaning and disinfection procedures must be continuously and effectively monitored to verify their suitability and effectiveness (Biocide Regulation 528/2012) [3].

However, self-checking in food industry is very limited to date and uses insensitive methods. The performances announced by the manufacturers are not subject to any evaluation or official validation. An inventory of tests for the detection of residues of disinfectant biocides has enabled us to show the few commercial methods available for self-monitoring [4]. In the context of collaborative projects, we have established that the detection limits were high, in the order of 0.5 to more than $2000 \mathrm{mg} / \mathrm{kg}$, i.e., 1000 times less sensitive than methods based on mass spectrometry [4]. In addition, these methods are not very selective (e.g., pH, conductivity) or too specific (e.g., ELISA). Despite the fact that their sensitivity thresholds are high, strip tests are the most used by food industries. This is why it is necessary to develop innovative tools, such as biosensors that are sensitive, 
fast, inexpensive, portable, and even online, to set up more efficient self-monitoring, and thus better protect consumer health. Many biosensors based on the inhibition of enzymatic activity were built for the detection of organophosphate pesticides (OPP) [5-8] These works draw inspiration for developing biosensors based on the use of enzymes as a recognition tool for the detection of disinfectant biocides. The results of the work on pesticides make it possible to reach detection limits of the order of $\mu \mathrm{g} / \mathrm{kg}$, i.e., 1000 times more sensitive.

\section{Enzymatic Biosensors for the Detection of Biocide Disinfectants}

\subsection{Development of Enzymatic Biosensors for the Detection of Biocide Disinfectants}

Due to the structural resemblance of organophosphate pesticides (OPP) to the substrate (i.e., acetylcholine) of acetylcholinesterase (AChE), these pesticides cause a reversible inhibition of this enzyme since they take the place of the substrate at the level of the active site of the enzyme [5]. The QAs have a chemical structure similar to acetylcholine, such as OPP. The reversible inhibitory effect of certain QACs (tetraethylammonium ions) on the activity of AChE (e.g., from electric eel) was demonstrated in 1952 by a manome-tric method [9].

This project will focus on enzymatic biosensors (i.e., AchE) for the detection of QACs, commonly used in the dairy industry (e.g., benzalkonium chloride (BAC), didecyldimethylammonium chloride (DDAC)) (Figure 1). Three transduction modes (colorimetric, fluorimetric, electrochemical) were selected because they have common advantages: simplicity, speed, low cost, little or no investment in hardware, miniaturization and portability [10]. The main challenges will be selectivity, accessibility of the active site of the immobilized enzyme, stability and repeatability. The poster file presented at the 8th International Symposium on Sensor Science (I3S) (17-26 May 2021) will be published as Supplementary Material.

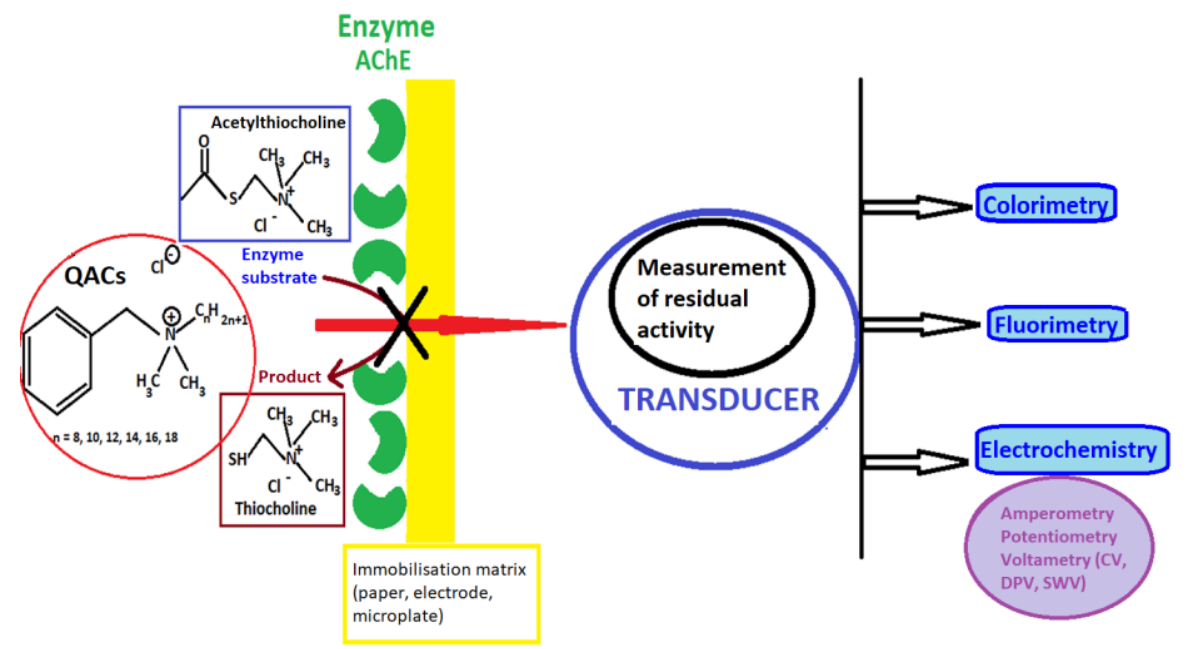

Figure 1. Description of the principle of biosensors based on the enzymatic inhibition of acetylcholinesterase (AChE) by quaternary ammoniums compounds (QACs).

One work focused on developing an electrochemical (conductimetric) biosensor based on AChE for the detection of two QACs (BAC, hexadecylpyridinium bromide) in an aqueous solution [11], while hundreds of articles have been published on the detection of pesticides in this way. Therefore, the strategies to be investigated for the detection of QACs by enzymatic biosensor and the recent development of nanotechnologies (i.e., Nanomaterials) make it possible to predict a sensitivity in line with our expectations [12]. 


\subsection{Intra-Laboratory Characterization of the Method Developed and Its Validation with Regard to the Expected Use}

Intra-laboratory characterization consists of determining each performance characteristic (e.g., sensitivity, selectivity, repeatability, robustness). Validation is the comparison of performance characteristics to expected performance criteria [13]. The validation of the developed methods will be carried out in accordance with the European regulations for veterinary medicinal products (European decision EC/2002/657 [14], European guideline for the validation of screening methods [15]) since there are no regulations for biocidal tests. In fact, the guideline which concerns the so-called screening methods (first instance of control) is applicable to disinfectant biocides since the analytical methods are the same.

The objective is to develop tests able to detect QACs below the Maximum Residue Limit (MRL) in milk $(0.1 \mathrm{mg} / \mathrm{kg})$ and with the lowest possible detection capabilities, i.e., $\mathrm{g} / \mathrm{kg}$ in rinsing water (in comparison with current tests which tend to have detection thresholds of the order of $\mathrm{mg} / \mathrm{kg}$ ).

\subsection{Use of Biosensors Developed and Validated for Sample Analysis (Rinsing Water, Milk)}

Finally, the developed methods will be used to analyze rinsing water collected during cleaning and disinfection operations to see if residual concentrations of QACs are detected. Regarding food products, the project will be focused on milk samples and dairy products following the results of the EFSA survey in 2012. Given the low sensitivities of the current tests used in the industry, the question addressed is whether it is possible, with more efficient methods, to detect low quantities $(0.1 \mu \mathrm{g} / \mathrm{kg})$ of biocidal residues in milk and dairy products for supplying exposure data needed for risk assessment. A quantitative physicochemical method based on liquid chromatography coupled with mass spectrometry in tandem (LC-MS/MS) for the detection of QACs to confirm positive results obtained with the biosensors will be used [16].

\section{Conclusions}

In a sector where very little research has been carried out and published, this project will make it possible to provide the dairy industry with more efficient self-control methods while remaining economically interesting. The knowledge and results acquired during this project will subsequently make it possible to open up enzymatic biosensors to other biocide disinfectants, and other food matrices than milk, or even to develop multiplexed biosensors for the simultaneous analysis of several families of disinfectants.

The study of milk samples and dairy products will provide us with a better understanding of the residual concentrations of QACs that may be present in these foodstuffs, following the use or misuse of these biocidal products during cleaning/disinfection procedures. This will allow the procedures to be corrected if necessary to ensure better control of the chemical risk. These self-monitoring tools will ultimately make it possible to generate data on the residual concentrations of disinfectant biocides which may be useful in the context of exposure risk assessments for consumers carried out by the Risk Assessment Department of ANSES.

Supplementary Materials: The supplementary file is available online at https:/ /www.mdpi.com/ article/10.3390/I3S2021Dresden-10077/s1. The poster file presented at the 8th International Symposium on Sensor Science (I3S) (17-26 May 2021) will be published as Supplementary Material.

Author Contributions: Writing-original draft preparation, V.G.; writing-review and editing, V.G. and C.S.; supervision, C.S. All authors have read and agreed to the published version of the manuscript.

Funding: This research received no external funding.

Institutional Review Board Statement: Not applicable.

Informed Consent Statement: Not applicable.

Conflicts of Interest: The authors declare no conflict of interest. 


\section{References}

1. Européenne, U. Règlement (CE) n 852/2004 du Parlement européen et du Conseil du 29 avril 2004 relatif à l’hygiène des denrées alimentaires. J. Off. 2004, 139, 1-54.

2. EFSA. Evaluation of monitoring data on residues of didecyldimethylammonium chloride (DDAC) and benzalkonium chloride (BAC). EFSA Supporting Publ. 2013, 10, 483E. [CrossRef]

3. Européenne, U. Règlement (UE) No. 528/2012 du Parlement européen et du Conseil du 22 mai 2012 concernant la mise à disposition sur le marché et l'utilisation des produits biocides. J. Off. 2012, 167, 1-123.

4. Soumet, C.; Valérie Gaudin, V.; Lancien, P.; Maris, P.; Slimani, K.; Rossi, N.; Hurtaux-Pessel, D. Inventaire des méthodes et kits pour la détection des résidus de biocides désinfectants. Rmt Actia Chlean 2020, 1-6. Available online: https: / www.actia-asso.eu/ projets/chlean-2/ (accessed on 6 April 2021).

5. Vargas-Bernal, R.; Rodríguez-Miranda, E.; Herrera-Pérez, G. Evolution and Expectations of Enzymatic Biosensors for Pesticides. Pestic. Adv. Chem. Bot. Pestic. 2012, 329-356. [CrossRef]

6. Pundir, C.S.; Malik, A.; Preety. Bio-sensing of organophosphorus pesticides: A review. Biosens. Bioelectron. 2019, 140, 111348. [CrossRef]

7. Marty, J.L.; Mionetto, N.; Noguer, T.; Ortega, F.; Roux, C. Enzyme sensors for the detection of pesticides. Biosens. Bioelectron. 1993, 8, 273-280. [CrossRef]

8. Walter, P.; Pepłowski, A.; Górski, Ł.; Janczak, D.; Jakubowska, M. Disposable, acetylcholinesterase-coated, screen-printed carbon electrodes for the determination of organophosphorus pesticides. Microelectron. Int. 2019, 36, 120-126. [CrossRef]

9. Bergmann, F.; Shimoni, A. Quaternary ammonium salts as inhibitors of acetylcholine esterase. Biochim. Biophys. Acta 1952, 8, 520-525. [CrossRef]

10. Gaudin, V. Advances in biosensor development for the screening of antibiotic residues in food products of animal origin-A comprehensive review. Biosens. Bioelectron. 2017, 90, 363-377. [CrossRef] [PubMed]

11. Kucherenko, I.S.; Soldatkin, O.O.; Arkhypova, V.M.; Dzyadevych, S.V.; Soldatkin, A.P. A novel biosensor method for surfactant determination based on acetylcholinesterase inhibition. Meas. Sci. Technol. 2012, 23, 065801. [CrossRef]

12. Gaudin, V. Contribution of Nanomaterials to the Development of Electrochemical Aptasensors for the Detection of Antimicrobial Residues in Food Products. Chemosensors 2021, 9, 69. [CrossRef]

13. Gaudin, V. State of the art in the validation of screening methods for the control of antibiotic residues: Is there a need for further development? Food Addit. Contam. Part A 2017, 34, 1528-1552. [CrossRef] [PubMed]

14. Directive, Implementing Council. Commission Decision (EC) $N^{\circ}$ 2002/657 of 12 August 2002 Implementing Council Directive 96/23/EC Concerning the Performance of Analytical Methods and Interpretation of Results; Official Journal of European Communities, European Commission: Brussels, Belgium, 2002; Volume L221, pp. 8-36.

15. CRL. Guideline for the Validation of Screening Methods for Residues of Veterinary Medicines (Initial Validation and Transfer). 2010, pp. 1-18. Available online: http://ec.europa.eu/food/food/chemicalsafety/residues/lab_analysis_en.htm \T1 $\backslash$ textgreater\{\}:Guideline_Validation_Screening_en.pdf (accessed on 20 January 2010).

16. Slimani, K.; Féret, A.; Pirotais, Y.; Maris, P.; Abjean, J.-P.; Hurtaud-Pessel, D. Liquid chromatography-tandem mass spectrometry multiresidue method for the analysis of quaternary ammonium compounds in cheese and milk products: Development and validation using the total error approach. J. Chromatogr. A 2017, 1517, 86-96. [CrossRef] [PubMed] 